\title{
A response to Prometheus editorials Volume 35 (2017), issues 2-4
}

As some readers may be aware, Taylor \& Francis will no longer be publishing Prometheus beyond Volume 35 (2017).

There are two Editorials published in Volume 35 (2017), issues 2-4, of Prometheus, which raise a number of points from the General Editor.

This note is in response to some of those points and is aimed at clarifying the publishing record for all readers.

On the journal's schedule:

- Prometheus has been publishing behind schedule for four years.

- During this period, we have regularly communicated with the General Editor regarding its copy flow, and have published each volume once copy was received from the General Editor.

- Having received and published the latest files from the General Editor for the 2017 volume, the journal remains a year behind schedule.

- This has led to a substantial loss of subscribers, and, in turn, our commercial decision to no longer publish the journal.

- It is for this reason alone we have chosen to stop publishing Prometheus, as the irregularity of its publishing means it has been unable to sustain its subscriber, and readership, base.

On the debate piece, as referenced in the Editorials:

- Libel advice protects (and is in the best interests of) all those involved in publishing. This includes journal editors, the publisher, and the authors themselves. It gives guidance on where material might be unlawful and where that material may expose those involved in its publication to legal liability.

- On the recommendation of our in-house legal team, it was decided to send a selection of papers from the proposed debate issue for pre-publication libel advice.

- Taylor \& Francis strongly believe in our work to uphold academic, editorial independence. Our guidance to the General Editor was never to shut down the proposed debate issue. Our role was to offer advice on the importance of peer review, in line with the journal's editorial policy, and to highlight any material legal risk in the papers under consideration.

- The Editorials discuss "the rules of the court, peculiar though they are, were to be applied to an academic journal". Libel law applies to all academic journals equally, as it does to every sort of publication. Those who are responsible for creating and publishing academic journals have to be mindful of the law in this area.

- We explained the libel advice we received to the General Editor. We attempted, in good faith, to support the General Editor in understanding and working through the legal risks raised whilst, at the same time, emphasising that this did not mean that Prometheus could not publish a debate on this issue. 